\title{
Effect of Pseudomonas aeruginosa on the Growth of Chickpea (Pisum sativum L.) Plant under Saline Condition
}

\author{
Ashish Gaurav $^{1 *}$ and Kumari Punam Pallavi \\ ${ }^{1}$ Department of Plant Physiology, Banaras Hindu University, Varanasi, (U.P.), India \\ ${ }^{2}$ Krishi Vigyan Kendra, Harnaut, Nalanda, Bihar-803110, India \\ *Corresponding author
}

\section{A B S T R A C T}

\section{Keywords}

Chickpea, PGPR,

IAA, Phosphate

solubilization

Article Info

Accepted:

12 September 2018

Available Online:

10 October 2018
Plant growth promoting rhizobacteria (PGPR) are beneficial bacteria that colonize plant roots and enhance plant growth by a wide variety of mechanisms. The isolate of PGPR designated as Pseudomonas aeruginosa strain (2CpS1) was successfully isolated from the soil and rhizosphere of roots of plants growing in fields, Almora district. Subsequently, an experiment was conducted under plant growth chamber where chickpea plants are grown in plastic cups containing soil and mixed with isolates of PGPR and were imposed with $150 \mathrm{mM} \mathrm{NaCl}$ to investigate the effect of PGPR on the growth of chickpea plant under salinity condition. Isolates of PGPR induced production of plant hormones (Indole acetic acid), phosphate solubilization and ammonia production to enhanced plant growth. The isolate resulted in a significant increase in shoot length, root length, leaf area and dry matter production of shoot and root of chickpea seedlings. Therefore, present study suggests that PGPR isolates $(2 \mathrm{CpS} 1)$ may be used as bio-fertilizers to enhance the growth and productivity of chickpea.

\section{Introduction}

Gram or Chickpea (Cicer arietinum Linn.), a member of family Fabaceae, is an ancient selfpollinated leguminous crop, diploid annual $(2 \mathrm{~N}=16)$ grown since 7000 B.C., in different areas of the world but its cultivation is mainly concentrated in semi-arid environments.

It is cultivated over an area of 8.21 million hectares giving 7.48 million tons (FAO, 2010) with an average yield of $9111 \mathrm{~kg} / \mathrm{ha}$. It is a major source of protein in human diet and animal feed. Salinity affects the availability of nutrients and water. Moreover, it induces osmotic stress, physiological drought which typically reduces the growth and photosynthesis in plants (Munnes and Tester, 2008). Growth reduction due to salinity is attributed to ion toxicity and nutrient imbalance, which causes not only high sodium $\left(\mathrm{Na}^{+}\right)$and chloride $\left(\mathrm{Cl}^{-}\right)$accumulation in plants, but also antagonistically affects the uptake of essential nutrient elements such as potassium $\left(\mathrm{K}^{+}\right), \quad$ calcium $\left(\mathrm{Ca}^{2+}\right)$ and magnesium $\left(\mathrm{Mg}^{2+}\right)$ in competition with $\mathrm{Na}^{+}$ and also nitrate $\left(\mathrm{NO}_{3}{ }^{-}\right)$in contrast with $\mathrm{Cl}^{-}$ (Sairam et al., 2002). Salinity can also affect growth and yield of most crops, high salinity is known to cause both hyper ionic and hyper 
osmotic effects in plants, leading to membrane disorganization, increase in activated oxygen species production and metabolic toxicity (Joseph \& Jini, 2011). PGPR are naturally occurring soil bacteria that aggressively colonize plant roots and benefit plants by providing growth promotion. Inoculation of crop plant with certain strains of PGPR at an early stage of development improves biomass production through direct effects on root and shoots growth. PGPR are reported to influence the growth, yield and nutrient uptake by an array of mechanisms.

They help in increasing nitrogen fixation in legumes, help in promoting free-living nitrogen-fixing bacteria, increase supply of other nutrients, such as phosphorus, sulphur, iron and copper, produce plant hormones, enhance other beneficial bacteria or fungi, control fungal and bacterial diseases and help in controlling insect pests. Pseudomonas aeruginosa is a gram-negative, unipolar motility aerobic rod shaped measuring 0.5 to $0.8 \mu \mathrm{m}$ belonging to the bacterial family Pseudomonadaceae. It is widespread in nature, inhabiting soil, water, plants and animals (including humans).

The objective of this work to investigate the effect of PGPR on growth and dry matter production in chickpea under salinity condition.

\section{Materials and Methods}

\section{Bacterial strains, isolation and identification}

Bacterial strains were isolated from the soil and rhizosphere of roots of plants growing in fields, Almora district, after serial dilution of soil solution on nutrient agar (NA) plates. Distinct colonies present on the plates were selected, purified by repeated culturing and maintained on NA slants at $4^{\circ} \mathrm{C}$.

\section{Phosphate solubilization by bacteria}

All isolates were first screened on Pikovskaya's agar plates for phosphate solubilization as described by Gaur (1990). Bacterial cultures were inoculated on centre of agar plate through inoculation loop under aseptic condition.

Inoculated plates were incubated for 3 days at $30^{\circ} \mathrm{C}$. Halo zone was obtained on Pikovskaya's agar plates. This halo zone showed positive phosphate solubilization ability (Table 1).

\section{Qualitative estimation of indole acetic acid}

Indole acetic acid (IAA) production was detected as described by Brick et al., (1991). For Qualitative estimation of IAA production Tryptone soy broth is used. Tryptone soy broth $(5.0 \mathrm{ml})$ tubes with and without tryptophan $(200 \mu 1 / \mathrm{ml})$ were inoculated with loopful of actively growing bacterial cultures aseptically and incubated for $48 \mathrm{~h}$ at $28^{\circ} \mathrm{C}$ under shaking condition. Fully grown cultures were centrifuged at $8000 \mathrm{rpm}$ for $10 \mathrm{~min}$.

The supernatant $(2 \mathrm{ml})$ was mixed with two drops of orthophosphoric acid and $4 \mathrm{ml}$ of the Salkowski reagent $(50 \mathrm{ml}, 35 \%$ of perchloric acid, $1 \mathrm{ml} \quad 0.5 \quad \mathrm{M} \quad \mathrm{FeCl}_{3}$ solution). Development of pink colour indicates positive test for IAA production.

\section{Production of ammonia}

Bacterial isolates were tested for the production of ammonia in peptone water. Freshly grown cultures were inoculated in $10 \mathrm{ml}$ peptone water in tube and incubated for $48-72 \mathrm{~h}$ at $36 \pm 2{ }^{\circ} \mathrm{C}$. Nessler's reagent $(0.5 \mathrm{ml})$ was added in each tube. Development of brown to yellow colour was a positive test for ammonia production (Cappuccino and Sherman, 1992). 


\section{Soil experiment}

Disease free and healthy seeds of chickpea (Cicer arientinum L.) cultivar JG-14, semierect having 92-95\% viability were obtained from the Department of Genetics and Plant Breeding, Jawaharlal Nehru Krishi Vishwa Vidyalaya, Jabalpur.

Chickpea seeds (cv. JW 14) were surface sterilized with $1 \% \quad \mathrm{NaOCl}$ (sodium hypochlorite) for 3-5 minutes and subsequently washed in sterilized distilled water 3-4 times and air dried. Cells of Pseudomonas aeruginosa (2CpS1) were grown in King's $\mathrm{B}$ broth (protease peptone $20 \mathrm{~g}+\mathrm{K}_{2} \mathrm{HPO}_{4} .3 \mathrm{H}_{2} \mathrm{O} \quad 1.908 \mathrm{~g}+\mathrm{MgSO}_{4} .7 \mathrm{H}_{2} \mathrm{O}$ $1.5 \mathrm{~g}+$ glycerol $15 \mathrm{~mL}+$ distilled water $985 \mathrm{~mL}$ ) for $24 \mathrm{~h}$ at $28 \pm 1^{\circ} \mathrm{C}$ under shaking conditions and finally cells in the exponential phase were centrifuged at $7000 \mathrm{rpm}$ for $15 \mathrm{~min}$ at $4^{\circ} \mathrm{C}$. The supernatant was discarded and pellets were washed with sterilized distilled water and resuspended to obtain a population of $10^{7} \mathrm{cfu}$ $\mathrm{mL}^{-1}$. This suspension was mixed with $1 \%$ Caboxy methyl cellulose (CMC). Surfacesterilized chickpea seeds of uniform size were then bacterized by dipping for $2 \mathrm{~h}$ into the bacterial suspension followed by air drying at room temperature under aseptic conditions.

\section{Salinity treatment imposition}

After 21 days of sowing, six pots each having Pseudomonas aeruginosa (2CpS1) treated seeds and non-treated seeds were imposed with $150 \mathrm{mM} \mathrm{NaCl}$ treatment and similar number of pots were not given any salinity treatment. The pots having salinity treatment were poured with $100 \mathrm{ml}$ of $150 \mathrm{mM} \mathrm{NaCl}$. The electrical conductivity measured at 14 and 28 days after salinity treatment imposition from soil lechate was 4.02 and $3.79 \mathrm{dSm}^{-1}$. The pots with different treatments were arranged in a randomized complete block design with triplicates of each treatment. The treatments were as follows: Control (Uninoculated Seeds); Plant + Microbe $(2 \mathrm{CpS} 1)$; Plant + Saline treatment; Plant + Microbe $(2 \mathrm{CpS} 1)+$ Saline treatment.

\section{Morphological and growth parameters}

Plant height of four tagged plant was measured in centimeter from the base of the plant to the growing tip of the main shoot with the help of a meter scale and expressed in $\mathrm{cm}$. The plant heights of four plants were averaged to obtain the height of per plant. Root length of a plant was measured in $\mathrm{cm}$ from the root tip to the base of the root. Root lengths of four plants were averaged. Leaf area was determined by dry weight method. Leaf area of two leaves were obtained using leaf area meter (Systronics 211) and such leaves along with remaining leaves were dried separately in hot air oven at $80^{\circ} \mathrm{C}$ for 72 hours. The dry weight of two leaves and rest of the leaves were recorded (Table 2).

\section{Total dry weight $\left(\mathrm{mg} \mathrm{plant}^{-1}\right)$}

All the plant parts (root, shoot and leaves) of four plants were well washed and the dry weight of cleaned plant samples recorded after putting them into an electric oven, first at the temperature of $110^{\circ} \mathrm{C}$ for an hour to kill the metabolic activities followed by the constant temperature of $70^{\circ} \mathrm{C}$ for a period of $72 \mathrm{~h}$. Regular weighing was made on digital electronic balance till a constant dry weight of the plant material was attained. Dry weight obtained was divided by four to obtain total dry weight per plant.

\section{Statistical analysis}

Simple CRD design was followed and analysis of variance was performed on the data as described by Panse and Sukhatme (1967). Critical difference (CD) values were calculated at 5 per cent probability level. 


\section{Results and Discussion}

\section{Plant growth promoting properties}

Screening results of PGPR traits are depicted in Table 1. Bacterial isolate Pseudomonas aeruginosa was tested for the qualitative estimation of Phosphorus solubilization and IAA production.

Studies on agar plates revealed that phosphate solubilizing microorganisms formed halo zones by solubilising suspended tricalcium phosphate on Pikovskaya's agar plates. Generally, halo zone was formed around the bacterial colony. The results showed that the bacteria $P$. aeruginosa strain $(2 \mathrm{CpS} 1)$ was formed maximum halo zone around the colony. This bacterial strain also showed positive response for ammonia \& IAA production.

Length and dry weight of shoot, root and leaves

The PGPR isolate significantly affected the length of chickpea seedlings. Results reveal that the shoot length increased in PGPR treated plants over uninoculated control. The highest shoot length $20.83 \mathrm{~cm} \mathrm{plant}^{-1}$, root length $27.13 \mathrm{~cm} \mathrm{plant}^{-1}$, leaf area 61.78 $\mathrm{cm}^{2}$ plant ${ }^{-1}$, root dry matter $68.77 \mathrm{mg} \mathrm{plant}^{-1} \&$ shoot dry matter $387.17 \mathrm{mg}$ plant $^{-1}$ was recorded in treatment of $P$. aeruginosa (2CpS1) isolate without $\mathrm{NaCl}$ treatment (Table 2). However, isolate show some positive response when seed is treated along with $\mathrm{NaCl}$ such as shoot length $19.31 \mathrm{~cm}$ plant $^{-1}$, root length $24.04 \mathrm{~cm} \mathrm{plant}^{-1}$, leaf area $53.39 \mathrm{~cm}^{2}$ plant $^{-1}$, root dry matter $64.91 \mathrm{mg}$ plant $^{-1}$ and shoot dry matter $370.96 \mathrm{mg}$ plant $^{-1}$ in comparison of control (shoot length $17.17 \mathrm{~cm} \mathrm{plant}^{-1}$, root length $19.90 \mathrm{~cm}$ plant $^{-1}$, leaf area $59.97 \mathrm{~cm}^{2}$ plant $^{-1}$, root dry matter $63.11 \mathrm{mg} \mathrm{plant}^{-1}$ and shoot dry matter 305.70 $\mathrm{mg}$ plant $^{-1}$ ). Also PGPR strain showed statistically significant increase of shoot dry weight over control. Root length ranged from 19.90 to $27.13 \mathrm{~cm}$ plant $^{-1}$. In this study, isolate significantly increased shoot length, root length, leaf area and dry matter production of chickpea plant

The ability of bacteria to produce IAA in the rhizosphere depends on the availability of precursors and uptake of microbial IAA by plant. Growth promotion may be attributed to other mechanisms such as production of plant growth promoting hormones in the rhizosphere and other PGP activities (Arshad and Frankenberger, 1993; Glick, 1995).

Production of IAA by Pseudomonas is a general characteristic of our test isolate. Bacterial strain Pseudomonas aeruginosa (2CpS1) showed maximum significant concentration of IAA, phosphorus solubilization and ammonia production. Similarly higher level of IAA production by Pseudomonas was recorded by other workers (Xie et al., 1996). Another important trait of PGPR, that may indirectly influence the plant growth, is the production of ammonia.

The isolate was able to produce ammonia. Phosphate solubilization was most frequently encountered by $P$. aeruginosa followed by $P$. putida, B. subtilis, $P$. polymyxa and least by $B$. boronophillus (Yadav et al., 2010).

P.aeruginosa produces largest halos around their colonies within 2 days of incubation than other isolates. Several species of fluorescent pseudomonas such as P. fluorescens NJ101 (Bano and Musarrat, 2004), P. aeruginosa (Jha et al., 2009) and Bacillus sp. (Ahmad et al., 2008) were reported as good phosphate solubilizers. Our results suggested that PGPR are able to enhance the production of IAA, solubilization of phosphorus and ammonia production, thereby improving growth of chickpea plant. 
Table.1 Production of IAA, phosphate solubilization and production of ammonia by PGPR

\begin{tabular}{|c|c|c|c|}
\hline Strain & Phosphate solubilization & IAA Production & Ammonia \\
\hline Psudomonas aeruginosa $(2 \mathrm{CpS} 1)$ & +ve & +ve & $+\mathrm{ve}$ \\
\hline
\end{tabular}

Table.2 Effect of plant growth promoting rhizobacteria on the growth of chickpea plants under salinity condition

\begin{tabular}{|c|c|c|c|c|c|}
\hline Treatment & $\begin{array}{c}\text { Shoot } \\
\text { length }(\mathrm{cm})\end{array}$ & $\begin{array}{c}\text { Root } \\
\text { length }(\mathrm{cm})\end{array}$ & $\begin{array}{l}\text { Leaf area } \\
\left(\mathrm{cm}^{2} / \text { plant }\right)\end{array}$ & $\begin{array}{c}\text { Shoot dry weight } \\
\text { (mg/plant) }\end{array}$ & $\begin{array}{c}\text { Root dry weight } \\
\text { (mg/plant) }\end{array}$ \\
\hline $\mathrm{T} 1$ & 17.17 & 19.90 & 59.97 & 305.7 & 63.11 \\
\hline $\mathrm{T} 2$ & 20.83 & 27.13 & 61.78 & 387.17 & 68.77 \\
\hline T3 & 16.03 & 18.83 & 48.83 & 258.95 & 54.88 \\
\hline $\mathrm{T} 4$ & 19.31 & 24.04 & 53.39 & 370.96 & 64.91 \\
\hline
\end{tabular}

T1: Control [No Pseudomonas aeruginosa (2CpS1) treatment $+\mathrm{No} \mathrm{NaCl}$ treatment]

T2: Pseudomonas aeruginosa $(2 \mathrm{CpS} 1)$ treatment $+\mathrm{No} \mathrm{NaCl}$ treatment

T3: No Pseudomonas aeruginosa (2CpS1) treatment $+150 \mathrm{mM} \mathrm{NaCl}$ treatment

T4: Pseudomonas aeruginosa (2CpS1) treatment $+150 \mathrm{mM} \mathrm{NaCl}$ treatment

Pseudomonas aeruginosa were observed most efficient inoculations for enhancement of shoot and root length and dry matter followed by Bacillus subtilis, Paenibacillus, Polymyxa and Bacillus boronophillus over control (Yadav et al., 2010). Plant growth of chickpea was enhanced due proper root colonization of plant growth promoting rhizobacteria which provide plant hormones (IAA), phosphorus and ammonia to plant. Similarly, PGPR have been shown to solubilize precipitated phosphates and enhance phosphate availability to chickpea that represent a possible mechanism of plant growth promotion under field condition (Verma et al., 2001; Verma et al., 2010).

The use of PGPR as inoculants bio-fertilizers is an efficient approach to replace chemical fertilizers and pesticides for sustainable chickpea cultivation in India and other developing countries. Further investigations, including efficiency test under green house and field conditions needed to clarify the role of PGPR as bio-fertilizers that exert beneficial effects on plant growth and development. Environmental stresses are limiting factors for agricultural productivity worldwide. These stresses not only decrease the yield of crops but also represent barriers to the introduction of crop plants into areas that are not suitable for crop cultivation.

Plant cells maintain total water potential during drought and salt stress by osmotic adjustment, a process to decrease water potential by accumulation of sugars or other compatible solutes such as proline, glycine betaine, mannitol, and sorbitol. Several transgenic plants which overproduce such solutes have shown some tolerance to drought and salt stress (Chinnusamy et al., 2005).

Osmotic adjustment is a mechanism by which plants acclimate to dehydration conditions, like drought and salt stress. Plants exhibit decreased water uptake and a subsequent reduction in leaf growth rate, which results in restricted photosynthetic capacity under salinity (Munns, 2002). Our results suggested that this strain show better response against salinity stress.

\section{References}

Ahmad, F., Ahmad, I., and Khan, M.S. 2008. Screening of free living rhizospheric bacteria for their multiple plant growth promoting activities. Microbiology Research, 163: 173-181. 
Arshad, M. and Frankenberger Jr., W.T. 1993. Microbial production of plant growth regulators. In: Blaine, F., Metting, Jr. (Eds.), Soil Microbial Ecology. Marcel and Dekker, Inc., New York, pp. 307-347.

Bano, N., and Musarrat, J. 2004. Characterization of a novel carbofuran degrading Pseudomonas sp. with collateral biocontrol and plant growth promoting potential. FEMS Microbiology Letter, 23: 13-17.

Brick, J.M., Bostock, R.M. and Silverstone, S.E. 1991. Rapid in situ assay for indole acetic acid production by bacteria immobilized on nitrocellulose membrane. Applied and Environmental Microbiology, 57: 535-538.

Cappuccino, J.C. and Sherman, N. 1992. In Microbiology: A Laboratory Manual, third ed. Benjamin/cummings Pub. Co. New York, pp. 125-179.

Chinnusamy, V., Jagendorf, A., and Zhu, J.K. 2005. Understanding and improving salt tolerance in plants. Crop Sci. 45, 437-448.

F.A.O., 2010. FAO production statistics, http://faostat.fao.org/site/567/, 2010.

Gaur, A.C. 1990. Physiological functions of phosphate solubilising micro-organisms. In: Gaur, A.C. (Ed.), Phosphate Solubilizing Microorganisms as Bio-fertilizers. Omega Scientific Publishers, New Delhi. pp. 1672.

Glick B. R. 1995. The enhancement of plant growth by free-living bacteria. Canadian Journal of Microbiology, 41: 109-117.

Jha, B.K., Pragash, M.G., Cletus, J., Raman, G. and Sakthivel, N. 2009. Simultaneous phosphate solubilization potential and antifungal activity of new fluorescent Pseudomonad strains, Pseudomonas aeruginosa, $P$. plecoglossicida and $P$. mosselii. World Journal of Microbiology and Biotechnology, 25: 573-581.
Joseph, B., and D. Jini. 2011. Development of salt stress-tolerant plants by gene manipulation of antioxidant enzymes. Asian J. Agric. Res., 5: 17-27.

Munns, R. 2002. Comparative physiology of salt and water stress. Plant Cell Environ. 25, 239-250.

Munns, R., and Tester, M. 2008. Mechanism of salinity tolerance. Annual Review of Plant Biology, 59: 651-681.

Panse, V. G. and Sukhatme, P. V. 1967. Statistical Methods for Agricultural Workers, 2nd edn, Indian Council of Agricultural Research, New Delhi,

Sairam, R.K., and Tyagi, A. 2004. Physiology and molecular biology of salinity stress tolerance in plants. Current science 86(3).

Verma, J.P., Yadav, J. and Tiwari, K.N. 2010. Application of Rhizobium sp. BHURC01 and plant growth promoting rhizobactria on nodulation, plant biomass and yields of chickpea (Cicer arietinum L.). International Journal of Agriculture Research, 5: 148-156.

Verma, S.C., Ladha, J.K., and Tripathi, A.K. 2001. Evaluation of plant growth promoting and coloization ability of endophytic diazotrophs from deep water rice. Journal of Biotechnology, 91: 127-141.

Xie, H., Pasternak, J.J., and Glick, B.R. 1996. Isolation and characterization of mutants of plant growth promoting rhizobacterium Pseudomonas putida GR 12-2 that over produce indole acetic acid. Current Microbiology, 32: 67-71.

Yadav, J., Verma, J.P., and Tiwari, K.N. 2010. Effect of plant growth promoting Rhizobacteria on seed germination and plant growth Chickpea (Cicer arietinum L.) under in Vitro conditions. Biological Forum - An International Journal, 2(2): 15-18 (2010).

\section{How to cite this article:}

Ashish Gaurav and Kumari Punam Pallavi. 2018. Effect of Pseudomonas aeruginosa on the Growth of Chickpea (Pisum sativum L.) Plant under Saline Condition. Int.J.Curr.Microbiol.App.Sci. 7(10): 15491554. doi: https://doi.org/10.20546/ijcmas.2018.710.173 